\title{
An alternative function for human uncoupling protein 3: protection of mitochondria against accumulation of nonesterified fatty acids inside the mitochondrial matrix.
}

Citation for published version (APA):

Schrauwen, P., Saris, W. H. M., \& Hesselink, M. K. C. (2001). An alternative function for human uncoupling protein 3: protection of mitochondria against accumulation of nonesterified fatty acids inside the mitochondrial matrix. Faseb Journal, 15(13), 2497-2502. https://doi.org/10.1096/fj.01-0400hyp

Document status and date:

Published: 01/01/2001

DOI:

10.1096/fj.01-0400hyp

Document Version:

Publisher's PDF, also known as Version of record

Please check the document version of this publication:

- A submitted manuscript is the version of the article upon submission and before peer-review. There can be important differences between the submitted version and the official published version of record.

People interested in the research are advised to contact the author for the final version of the publication, or visit the DOI to the publisher's website.

- The final author version and the galley proof are versions of the publication after peer review.

- The final published version features the final layout of the paper including the volume, issue and page numbers.

Link to publication

\footnotetext{
General rights rights.

- You may freely distribute the URL identifying the publication in the public portal. please follow below link for the End User Agreement:

www.umlib.nl/taverne-license

Take down policy

If you believe that this document breaches copyright please contact us at:

repository@maastrichtuniversity.nl

providing details and we will investigate your claim.
}

Copyright and moral rights for the publications made accessible in the public portal are retained by the authors and/or other copyright owners and it is a condition of accessing publications that users recognise and abide by the legal requirements associated with these

- Users may download and print one copy of any publication from the public portal for the purpose of private study or research.

- You may not further distribute the material or use it for any profit-making activity or commercial gain

If the publication is distributed under the terms of Article 25fa of the Dutch Copyright Act, indicated by the "Taverne" license above,

Download date: 26 Apr. 2023 


\title{
An alternative function for human uncoupling protein 3: protection of mitochondria against accumulation of nonesterified fatty acids inside the mitochondrial matrix
}

\author{
PATRICK SCHRAUWEN, ${ }^{1}$ WIM H. M. SARIS, AND MATTHIJS K. C. HESSELINK* \\ Department of Human Biology and *Department of Movement Sciences, \\ Maastricht University, The Netherlands
}

\begin{abstract}
The physiological function of the human uncoupling protein 3 UCP3, which was discovered in 1997 , is unknown. Here we evaluate the available data on human UCP3 expression and show that UCP3 is up-regulated in situations where fatty acid delivery to the mitochondria exceeds oxidative capacity, whereas down-regulation of UCP3 is observed when oxidative capacity is enhanced. With a surplus of fatty acid delivery, accumulation of nonesterified fatty acids in the cytoplasm is likely to occur. Although the inner mitochondrial membrane provides a barrier for nonesterified fatty acids, neutral nonesterified fatty acids can partition into the phospholipid bilayer and flip-flop to the other side of the membrane, where they can be released into the mitochondrial matrix. Due to $\mathrm{pH}$ differences, these nonesterified fatty acids will be protonated. Because fatty acid anions can neither be metabolized inside the matrix or cross the inner mitochondrial membrane, accumulation of nonesterified fatty acids inside the matrix might occur. Therefore, we postulate that UCP3 is required for the outward translocation of fatty acids from the mitochondrial matrix. In this way, UCP3 is involved in the protection of mitochondria against accumulation of nonesterified fatty acids inside the mitochondrial matrix.-Schrauwen, P., Saris, W. H. M., Hesselink, M. K. C. An alternative function for human uncoupling protein 3: protection of mitochondria against accumulation of nonesterified fatty acids inside the mitochondrial matrix. FASEB J. 15, 2497-2502 (2001)
\end{abstract}

Key Words: UCP3 $\cdot$ fatty acid metabolism $\cdot$ fatty acid transport

Due to THEIR HOMOLOGY WITH UCP1, the recently discovered human uncoupling proteins UCP2 and UCP3 are suggested to play a role in human energy metabolism and obesity (1-3). UCP2 and UCP3 encode for proteins that are located in the inner mitochondrial membrane, where they can uncouple respiration from ATP production, thereby dissipating energy as heat. When expressed in yeast, these uncoupling proteins have been shown to lower the proton gradient across the inner mitochondrial membrane (4-7), but the mechanism by which they do so is under debate. It has been proposed that UCPs either transport protons into the mitochondrial matrix (8) or that the proton gradient is lowered by cycling of fatty acids in the inner mitochondrial membrane, with a role for UCP in transporting nonesterified fatty acid anions out of the matrix (9). In contrast to UCP2, which is ubiquitously expressed in virtually all tissues, UCP3 is restricted to skeletal muscle and brown adipose tissue (10). In humans, skeletal muscle is responsible for a major part of energy expenditure and therefore UCP3 has been implicated in the regulation of the latter. Since the discovery of UCP3 in 1997, many data have been published on the possible function of UCP3. Most data have been obtained in cellular systems and/or animal models and fewer have been obtained in humans. Here we will review the available data in humans and postulate a new function for the human uncoupling protein 3 .

\section{IS HUMAN UCP3 INVOLVED IN ENERGY EXPENDITURE?}

Initially, research regarding the function of UCP3 focused on a possible role of UCP3 in energy expenditure. Linkage and association studies have indeed suggested a link between UCP3 and energy expenditure $(11,12)$, although an absence of association between UCP3 and energy expenditure has also been reported (13). In Pima Indians, we found that the mRNA expression of UCP3 was positively correlated with sleeping metabolic rate, which accounts for $\sim 60 \%$ of total energy expenditure in humans (14). To further examine whether UCP3 plays a role in energy expenditure, we compared UCP3 mRNA levels in skeletal muscle of endurance trained and untrained subjects. It is known

\footnotetext{
${ }^{1}$ Correspondence: Nutrition and Toxicology Research Institute Maastricht (NUTRIM), Department of Human Biology, Maastricht University, P.O. Box 616, 6200 MD Maastricht, The Netherlands. E-mail: p.schrauwen@hb.unimaas.nl
} 
that endurance training alters energy metabolism, with trained subjects having an increased energy efficiency (15, 16). We found that endurance trained subjects had lower amounts of UCP3 mRNA per mitochondria and UCP3 mRNA expression was highly correlated with (mechanical) energy efficiency (17). Buemann et al. (18) recently found an association between a polymorphism in the UCP2 gene (which is close to the UCP3 gene) and mechanical energy efficiency, which indirectly supports the relation between UCP3 and energy efficiency. Indirect evidence for a role of UCP3 in energy expenditure comes from the finding that UCP3 mRNA and UCP3 protein are reduced after weight loss (19-21). Weight reduction results in a decrease in basal metabolic rate, even when expressed per unit of fat free mass, and it has been proposed that this reduced energy expenditure is responsible for the rapid weight regain observed in postobese subjects (22). Finally, Barbe et al. (23) reported that treatment of lean subjects for 14 days with thyroid hormone, known to increase metabolic rate, resulted in the specific up-regulation of skeletal muscle UCP3 mRNA expression. Together, these data do provide evidence for a relation between skeletal muscle UCP3 and human energy metabolism. Moreover, a role for UCP3 in energy expenditure is underscored by the finding that mice overexpressing UCP3 in skeletal muscle are hyperphagic but weigh less than control mice (24). However, whether the primary physiological function of UCP3 is the regulation of energy expenditure is under debate. For example, UCP3 knockout mice have normal energy expenditure and are not obese $(25,26)$. In humans, fasting, a condition associated with energy conservation (27), results in the up-regulation of UCP3 mRNA expression (28). These data are thus inconsistent with a role for human UCP3 in the regulation of energy expenditure and have urged researchers to search for a new function for human UCP3. Taken together, the available data show that UCP3 is related to human energy expenditure, but the primary role of UCP3 does not seem to be directly related to the regulation of energy expenditure.

\section{IS HUMAN UCP3 INVOLVED IN FATTY ACID METABOLISM?}

An explanation for the unexpected up-regulation of UCP3 during fasting comes from the observation that free fatty acids (FFA) up-regulate UCP3 mRNA expression, both in rodents (29) and in humans (30). During fasting and conditions of elevated plasma FFA levels, however, fat oxidation is also increased, and it has therefore been suggested that UCP3 is involved in the handling of lipids as a fuel (31). Several studies have been performed with humans to elucidate the potential function of UCP3 in fatty acid metabolism.

\section{Acute exercise and UCP3}

During and after acute endurance exercise, energy expenditure, plasma FFA levels, and fat oxidation are rapidly increased. In rodents, a rapid up-regulation of UCP3 after acute exercise was observed (32-34). In humans, the effect of acute exercise on UCP3 expression has also been studied. We did not observe an effect of $80 \mathrm{~min}$ of exhaustive cycling exercise on UCP3 mRNA expression measured immediately after the exercise bout (17). Pilegaard et al. (35) observed that UCP3 mRNA was up-regulated 1 to $4 \mathrm{~h}$ after an acute bout of exercise. In both studies, the possible effect of plasma FFA levels on UCP3 expression was not addressed. Therefore, we recently investigated whether the up-regulation of UCP3 mRNA expression after acute exercise is an effect of exercise per se or an effect of increased levels of plasma FFA (36). Subjects performed a $2 \mathrm{~h}$ exercise bout twice, once in the fasted state and once with the ingestion of glucose, and UCP3 mRNA expression was measured 1 and $4 \mathrm{~h}$ postexercise. This protocol resulted in marked differences in plasma FFA levels and fat oxidation during and after exercise between the glucose-fed and fasted state. Four hours after exercise, UCP3 mRNA was up-regulated, but only in the fasted state. Therefore, the effect of exercise on UCP3 mRNA expression is not an exercise effect per se but an effect of elevated plasma FFA levels and/or increased fat oxidation (36).

\section{High-fat diets and UCP3}

Another condition in which fatty acid metabolism is affected is during the consumption of high-fat diets. Prolonged consumption of a high-fat diet results in a gradual increase in fat oxidation, without a change in fasting plasma FFA levels (37). We examined the effect of prolonged consumption of high-fat diet (60 en $\%$ as fat) on UCP3 mRNA expression and found that UCP3 mRNA tended to increase after a $4 \mathrm{wk}$ period of high-fat diet consumption (38), consistent with data obtained in rodents $(29,39)$. In-depth evaluation of the data showed that the increase in UCP3 mRNA on the high-fat diet was related to the subjects' proportion of type IIA muscle fibers, with the highest increase in UCP3 mRNA in those subjects with the highest amount of type IIA muscle fibers (38). Type IIA muscle fibers are capable of oxidizing both carbohydrates and fatty acids, whereas type I and IIB muscle fibers are enzymatically equipped for the oxidation of fat and carbohydrate, respectively. These results led us to examine whether UCP3 protein is differentially expressed in the different muscle fibers. Surprisingly, we found that UCP3 is abundantly expressed in type IIB muscle fibers, moderately in type IIA fibers, and expressed to a much lower extent in type I muscle fibers (40). High expression of UCP3 in type IIB muscle fibers, which are not able to oxidize fatty acids, is inconsistent with a role for UCP3 in the oxidation of fatty acids.

\section{Endurance training}

As we discussed above, endurance training is associated with an increase in energy efficiency and a down- 
regulation of UCP3 expression. However, a typical feature of endurance trained athletes is an increased fat oxidation capacity (41). We recently performed a study in which we examined the effect of a 3 month training program in lean, untrained subjects on UCP3 expression and fat oxidation. Although muscle biopsies were available only in five subjects, we found a significant decrease in UCP3 protein after the training program (Fig. 1A), whereas triglyceride-derived fat oxidation (as determined by stable isotope tracer technique) was increased and plasma FFA levels were unaltered (unpublished results). As shown in Fig. $1 B$, there was an inverse relation between the change in UCP3 protein and the change in fat oxidation: those subjects whose fat oxidation capacity under standardized conditions increased the most showed the most pronounced decrease in UCP3.

\section{Weight reduction and thyroid hormone treatment}

Two other conditions known to influence UCP3 expression are also associated with changes in fatty acid metabolism. First, weight reduction has been shown to decrease UCP3 expression, and this down-regulation of UCP3 could be related to changes in energy expenditure, as discussed above. However, fat oxidation capacity is increased and plasma FFA levels are reduced after weight reduction, raising the possibility that UCP3 content is related to these changes in fatty acid metabolism. Second, the specific up-regulation of UCP3 with thyroid hormone treatment could not only be related to the increase in metabolic rate, but thyroid treatment also results in the stimulation of lipolysis and fat oxidation (42).

In summary, these data show a relation between human UCP3 content and fatty acid metabolism and suggest a physiological role for UCP3 in fat metabolism.

\section{IS UCP3 REGULATED BY PLASMA FFA LEVELS AND/OR FAT OXIDATION?}

So far, two explanations have been given for the observed relation between UCP3 and fatty acid metab-
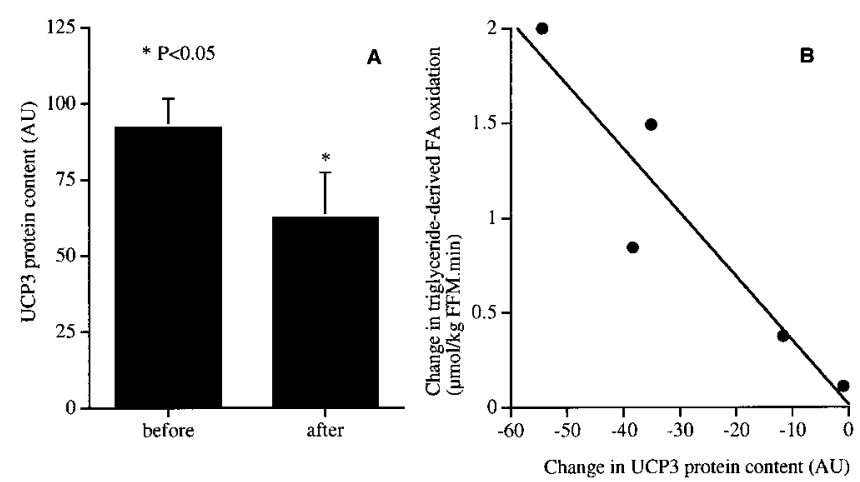

Figure 1. A) The effect of 3 months of endurance training on UCP3 protein content $(n=5) . * P<0.05$. B) The relation $(r=0.93, P=0.02, n=5)$ between changes in fat oxidation and UCP3 protein induced by endurance training. olism. The first explanation simply states that plasma nonesterified fatty acids are ligands for PPARs, and the PPARs have been shown to regulate UCP3 gene expression (43). A second explanation suggests a role for UCP3 in the handling of lipids as a fuel (44). However, both concepts fail to fully explain the data outlined above. Although the up-regulation of UCP3 during fasting, acute exercise, and thyroid treatment could be attributed to an elevation of plasma nonesterified fatty acid levels, the up-regulation of UCP3 after long-term high-fat diet cannot necessarily be attributed to changes in plasma FFA levels, since on the long-term high-fat diet consumption does not increase fasting plasma nonesterified fatty acid levels. Similarly, the down-regulation of UCP3 with endurance training is not accompanied by a reduction in plasma nonesterified fatty acid levels. Therefore, the relation between UCP3 and fatty acid metabolism cannot be explained solely by the effect of plasma nonesterified fatty acid levels on UCP3. On the other hand, the explanation that UCP3 is involved in the handling of lipids as a fuel is not fully compatible with the available data. Weight reduction and endurance training lead to an increase in the capacity to oxidize fat whereas UCP3 is downregulated. Moreover, the fact that UCP3 protein expression is highest in type IIB muscle fibers, which are hardly able to oxidize fatty acids, might be the most direct evidence against a role for UCP3 in the handling of lipid as a fuel.

\section{AN ALTERNATIVE FUNCTION: UCP3 IS A TRANSPORTER OF NONESTERIFIED FATTY ACIDS OUT OF MITOCHONDRIA}

As mentioned earlier, UCP3 could perform its uncoupling activity by transporting nonesterified fatty acid anions across the inner mitochondrial membrane (9). Oxidation of nonesterified fatty acids from cytoplasm requires several subsequent steps to transport them into the mitochondrial matrix where $\beta$-oxidation takes place. In the cytoplasm, nonesterified fatty acids are esterified to fatty acyl-CoA by an enzyme called fatty acyl-CoA synthetase. Fatty acyl-CoA (but also nonesterified fatty acids) can easily cross the outer mitochondrial membrane. However, the inner mitochondrial membrane is impermeable for long-chain fatty acyl-CoA and therefore, the acyl-CoA ester is converted to acyl-carnitine, by CPT1 located at the outer mitochondrial membrane. Acyl-carnitine crosses the inner mitochondrial membrane and is reconverted to acyl-CoA in the matrix by CPT2. Since only fatty acyl-CoA is able to enter the $\beta$-oxidation, this sequence of steps is a prerequisite for directing nonesterified fatty acids into the mitochondrial matrix for oxidation.

Nonesterified fatty acids can easily cross the outer mitochondrial membrane. Although the inner mitochondrial membrane provides a barrier for nonesterified fatty acids, neutral nonesterified fatty acids (but not anions) can partition into the phospholipid bilayer 
Figure 2. Schematic representation of the putative physiological role of UCP3. Nonesterified fatty acids (FA) present in the cytoplasm can be esterified to fatty acyl-CoA by the enzyme fatty acyl-CoA synthetase (FAS). Fatty acyl-CoA crosses the outer mitochondrial membrane, where it is converted to fatty acyl-carnitine by CPT1. Fatty acyl-carnitine is able to cross the inner mitochondrial membrane; once inside the mitochondrial matrix, it is reconverted to fatty acyl-CoA by CPT2. Fatty acyl-CoA can be directed to oxidation. However, the outer mitochondrial membrane is permeable for nonesterified fatty acids and part of the cytoplasmic FA therefore will be able to cross this membrane. The inner mitochondrial membrane is not permeable for FA, but FA are able to incorporate into the membrane lipid bilayer and flip-flop to the matrix side of the membrane. FA released inside the matrix will be deprotonated due to the proton gradient. Since FA anions cannot flip-flop back or be metabolized (due to lack of FAS in the matrix), accumulation of FA anions would occur. To prevent the deleterious effects of FA anion accumulation in the mitochondrial matrix, UCP3 is involved in the outward translocation of these FA anions.

and can flip-flop to the matrix side of the membrane $(45,46)$. Here, these neutral nonesterified fatty acids could enter the mitochondrial matrix, where they will be deprotonated due to the proton gradient across the inner mitochondrial membrane. In this way, nonesterified fatty acids are able to lower the proton gradient (uncoupling effect). Once in the matrix, the formed nonesterified fatty acid anion cannot be converted to fatty acyl-CoA due to lack of fatty acyl-CoA synthetase in the matrix. Since nonesterified fatty acid anions are not able to flip-flop back across the inner mitochondrial membrane (46), nonesterified fatty acid anions would accumulate inside the mitochondrial matrix. It is known that in the mitochondrial matrix, nonesterified fatty acids have deleterious effects on mitochondrial function due, for example, to lipid peroxidation. Therefore, these nonesterified fatty acids need to be transported out of the mitochondrial matrix. Here UCP3 could be involved in the outward translocation of nonesterified fatty acids anions out of the mitochondria (Fig. 2).

We hypothesize that the physiological function of UCP3 is to protect mitochondria from accumulation of nonesterified fatty acids inside the mitochondrial matrix, especially in situations where fatty acid delivery exceeds oxidation. We believe that, although the major part of the nonesterified fatty acids delivered to mitochondria will be subject to oxidation, a small amount of nonesterified fatty acids might reach the mitochondrial matrix, and it is known that nonesterified fatty acids are potentially toxic. The entrance of nonesterified fatty acids inside the matrix may play a significant role in situations where fatty acid supply to the mitochondria does not match oxidation. Reevaluating the data described above indeed shows that UCP3 is up-regulated in situations where fatty acid supply exceeds fat oxida- tion capacity (fasting, high-fat diet, T3 treatment, acute exercise) whereas UCP3 is down-regulated in situations where fat oxidation capacity is improved (endurance training, weight reduction). The high expression of UCP3 in type IIB muscle fibers is also consistent with this hypothesis, since these muscle fibers, which are barely able to oxidize fatty acids, especially need to be protected against mitochondrial nonesterified fatty acids accumulation. Type I muscle fibers, on the other hand have a high capacity to oxidize fatty acids and therefore are less prone to accumulation of nonesterified fatty acids; thus, UCP3 content can be low. This protective function of UCP3 is associated with the outward translocation of nonesterified fatty acids anions and therefore will decrease the proton gradient across the inner mitochondrial membrane, thereby uncoupling respiration from ATP production. Because of this primary function of UCP3, UCP3 still indirectly influences energy metabolism, explaining the relation between UCP3 and energy metabolism.

In conclusion, we propose the hypothesis that the primary function of UCP3 is the outward translocation of nonesterified fatty acids from the mitochondrial matrix, especially in situations when fatty acid supply exceeds oxidation. Because of this function, UCP3 uncouples mitochondrial respiration, explaining its relation with human energy metabolism.

$\mathbf{F} \mathbf{J}$

\section{REFERENCES}

1. Schrauwen, P., Walder, K., and Ravussin, E. (1999) Human uncoupling proteins and obesity. Obes. Res. 7, 97-105

2. Ricquier, D., and Bouillaud, F. (2000) The uncoupling protein homologues: UCP1, UCP2, UCP3, StUCP and AtUCP. Biochem. J. 345, 161-179 
3. Boss, O., Muzzin, P., and Giacobino, J.-P. (1998) The uncoupling proteins, a review. Eur. J. Endocrinol. 139, 1-9

4. Gong, D.-W., He, Y., Karas, M., and Reitman, M. (1997) Uncoupling protein-3 is a mediator of thermogenesis regulated by thyroid hormone. $\beta$ 3-adrenergic agonists, and leptin. J. Biol. Chem. 272, 24129-24132

5. Fleury, C., Neverova, M., Collins, S., Raimbault, S., Champigny, O., Levi-Meyrueis, C., Bouillaud, F., Seldin, M. F., Surwit, R. S., and Ricquier, D. (1997) Uncoupling protein-2: a novel gene linked to obesity and hyperinsulinemia. Nat. Genet. 15, 269-273

6. Boss, O., Samec, S., Kühne, F., Bijlenga, P., AssimacopoulosJeannet, F., Seydoux, J., Giacobino, J.-P., and Muzzin, P. (1998) Uncoupling protein-3 expression in rodent skeletal muscle is modulated by food intake but not by changes in environmental temperature. J. Biol. Chem. 273, 5-8

7. Gimeno, R. E., Dembski, M., Weng, X., Deng, N., Shyjan, A. W., Gimeno, C. J., Iris, F., Ellis, S. J., Woolf, E. A., and Tartaglia, L. A. (1997) Cloning and characterization of an uncoupling protein homolog: a potential molecular mediator of human thermogenesis. Diabetes 46, 900-906

8. Klingenberg, M., Echtay, K. S., Bienengraeber, M., Winkler, E., and Huang, S. G. (1999) Structure-function relationship in UCP1. Int. J. Obes. Relat. Metab. Disord. 23 (Suppl. 6), S24-S29

9. Jezek, P., Engstová, H., Zácková, M., Vercesi, A. E., Costa, A. D. T., Arruda, P., and Garlid, K. D. (1998) Fatty acid cycling mechanism and mitochondrial uncoupling proteins. Biochim. Biophys. Acta 1365, 319-327

10. Boss, O., Samec, S., Paoloni-Giacobino, A., Rossier, C., Dulloo, A., Seydoux, J., Muzzin, P., and Giacobino, J.-P. (1997) Uncoupling protein-3: a new member of the mitochondrial carrier family with tissue-specific expression. FEBS Lett. 408, 39-42

11. Walder, K., Norman, R. A., Hanson, R. L., Schrauwen, P., Neverova, M., Jenkinson, C. P., Easlick, J., Warden, C. H., Pecqueur, C., and Raimbault, S. (1998) Association between uncoupling protein polymorphisms (UCP2-UCP3) and energy metabolism/obesity in Pima Indians. Hum. Mol. Genet. 7, 14311435

12. Bouchard, C., Pérusse, L., Chagnon, Y. C., Warden, G., and Ricquier, D. (1997) Linkage between markers in the vicinity of the uncoupling protein 2 gene and resting metabolic rate in humans. Hum. Mol. Genet. 6, 1887-1889

13. Klannemark, M., Orho, M., and Groop, L. (1998) No relationship between identified variants in the uncoupling protein 2 gene and energy expenditure. Eur. J. Endocrinol. 139, 217-223

14. Schrauwen, P., Xia, J., Bogardus, C., Pratley, R., and Ravussin, E. (1999) Skeletal muscle UCP3 expression is a determinant of energy expenditure in Pima Indians. Diabetes 48, 146-149

15. Gardner, A. W., Poehlman, E. T., and Corrigan, D. L. (1989) Effect of endurance training on gross energy expenditure during exercise. Hum. Biol. 61, 559-569

16. Gissane, C., Corrigan, D. L., and White, J. A. (1991) Gross efficiency responses to exercise conditioning in adult males of various ages. J. Sports Sci. 9, 383-391

17. Schrauwen, P., Troost, F. J., Xia, J., Ravussin, E., and Saris, W. H. M. (1999) Skeletal muscle UCP2 and UCP3 expression in trained and untrained male subjects. Int. J. Obes. Relat. Metab. Disord. 23, 966-972

18. Buemann, B., Schierning, B., Toubro, S., Bibby, B., Sorensen, T., Dalgaard, L., Pedersen, O., and Astrup, A. (2001) The association between the val/ala- 55 polymorphism of the uncoupling protein 2 gene and exercise efficiency. Int. J. Obes. Relat. Metab. Disord. 25, 467-471

19. Esterbauer, H., Oberkofler, H., Dallinger, G., Breban, D., Hell, E., Krempler, F., and Patsch, W. (1999) Uncoupling protein-3 gene expression: reduced skeletal muscle mRNA in obese humans during pronounced weight loss. Diabetologia 42, 302309

20. Vidal-Puig, A., Rosenbaum, M., Considine, R. C., Leibel, R. L. Dohm, G. L., and Lowell, B. B. (1999) Effects of obesity and stable weight reduction on UCP2 and UCP3 gene expression in humans. Obes. Res. 7, 133-140

21. Schrauwen, P., Schaart, G., Saris, W. H. M., Slieker, L. J., Glatz, J. F. C., Vidal, H., and Blaak, E. E. (2000) The effect of weight reduction on skeletal muscle UCP2 and UCP3 mRNA expression and UCP3 protein content in type II diabetic subjects. Diabetologia 43, 1408-1416
22. Leibel, R. L., Rosenbaum, M., and Hirsch, J. (1995) Changes in energy expenditure resulting from altered body weight. $N$. Engl. J. Med. 332, 621-628

23. Barbe, P., Larrouy, D., Boulanger, C., Chevillotte, E., Viguerie, N., Thalamas, C., Trastoy, M. O., Roques, M., Vidal, H., and Langin, D. (2001) Triiodothyronine-mediated up-regulation of UCP2 and UCP3 mRNA expression in human skeletal muscle without coordinated induction of mitochondrial respiratory chain genes. FASEB J. 15, 13-15

24. Clapham, J. C., Arch, J. R., Chapman, H., Haynes, A., Lister, C., Moore, G. B., Piercy, V., Carter, S. A., Lehner, I., and Smith, S. A. (2000) Mice overexpressing human uncoupling protein-3 in skeletal muscle are hyperphagic and lean. Nature (London) 406, 415-418

25. Vidal-Puig, A. J., Grujic, D., Zhang, C. Y., Hagen, T., Boss, O., Ido, Y., Szczepanik, A., Wade, J., Mootha, V., and Cortright, R. (2000) Energy metabolism in uncoupling protein 3 gene knockout mice. J. Biol. Chem. 275, 16258-16266

26. Gong, D. W., Monemdjou, S., Gavrilova, O., Leon, L. R., Marcus-Samuels, B., Chou, C. J., Everett, C., Kozak, L. P., Li, C., and Deng, C. (2000) Lack of obesity and normal response to fasting and thyroid hormone in mice lacking uncoupling protein-3. J. Biol. Chem. 275, 16251-16257

27. Keys, A., Brozek, J., Henschel, A., Mickelsen, O., and Taylor, H. L. (1950) The Biology of Human Starvation, University of Minnesota Press, Minneapolis

28. Millet, L., Vidal, H., Andreelli, F., Larrouy, D., Riou, J.-P., Ricquier, D., Laville, M., and Langin, D. (1997) Increased uncoupling protein-2 and -3 mRNA expression during fasting in obese and lean humans. J. Clin. Invest. 100, 2665-2670

29. Weigle, D. S., Selfridge, L. E., Schwartz, M. W., Seeley, R. J., Cummings, D. E., Havel, P. J., Kuijper, J. L., and Bertran del Rio, H. (1998) Elevated free fatty acids induce uncoupling protein 3 expression in muscle. A potential explanation for the effect of fasting. Diabetes 47, 298-302

30. Khalfallah, Y., Fages, S., Laville, M., Langin, D., and Vidal, H. (2000) Regulation of uncoupling protein-2 and uncoupling protein-3 mRNA expression during lipid infusion in human skeletal muscle and subcutaneous adipose tissue. Diabetes 49, 25-31

31. Samec, S., Seydoux, J., and Dulloo, A. G. (1999) Skeletal muscle UCP3 and UCP2 gene expression in response to inhibition of free fatty acid flux through mitochondrial beta-oxidation. Pfluegers Arch. 438, 452-457

32. Zhou, M., Lin, B. Z., Coughlin, S., Vallega, G., and Pilch, P. F. (2000) UCP-3 expression in skeletal muscle: effects of exercise, hypoxia, and AMP-activated protein kinase. Am. J. Physiol. 279, E622-E629

33. Tsuboyama-Kasaoka, N., Tsunoda, N., Maruyama, K., Takahashi, M., Kim, H., Ikemoto, S., and Ezaki, O. (1998) Up-regulation of uncoupling protein 3 (UCP3) mRNA by exercise training and down-regulation of UCP3 by denervation in skeletal muscles. Biochem. Biophys. Res. Commun. 247, 498-503

34. Cortright, R. N., Zheng, D., Jones, J. P., Fluckey, J. D., DiCarlo, S. E., Grujic, D., Lowell, B. B., and Dohm, G. L. (1999) Regulation of skeletal muscle UCP-2 and UCP-3 gene expression by exercise and denervation. Am. J. Physiol. 276, E217-E221

35. Pilegaard, H., Ordway, G. A., Saltin, B., and Neufer, P. D. (2000) Transcriptional regulation of gene expression in human skeletal muscle during recovery from exercise. Am. J. Physiol. 279, E806-E814

36. Schrauwen, P., Hesselink, M. K. C., Vaartjes, I., Kornips, E., Saris, W. H. M., Giacobino, J.-P., and Russell, A. (2001) The effect of acute exercise on uncoupling protein 3 is a fat metabolism mediated effect. Am J. Physiol. In press

37. Schrauwen. P., Marken Lichtenbelt, W. D. v., Saris, W. H. M., and Westerterp, K. R. (1997) Changes in fat oxidation in response to a high-fat diet. Am. J. Clin. Nutr. 66, 276-282

38. Schrauwen, P., Hoppeler, H., Billeter, R., Bakker, A., and Pendergast, D. (2001) Fiber type dependent upregulation of human skeletal muscle UCP2 and UCP3 mRNA expression by high-fat diet. Int. J. Obes. Relat. Metab. Disord. 25, 449-456

39. Matsuda, J., Hosoda, K., Itoh, H., Son, C., Doi, K., Tanaka, T., Fukunaga, Y., Inoue, G., Nishimura, H., and Yoshimasa, Y. (1997) Cloning of rat uncoupling protein-3 and uncoupling protein-2 cDNAs: their gene expression in rats fed high-fat diet. FEBS Lett. 418, 200-204 
40. Hesselink, M. K. C., Keizer, H. A., Borghouts, L. B., Schaart, G., Kornips, C. F. P., Slieker, L. J., Sloop, K. W., Saris, W. H. M., and Schrauwen, P. (2001) Protein expression of UCP3 differs between human type 1 , type $2 \mathrm{a}$ and type $2 \mathrm{~b}$ fibers. FASEB J. 15, 101096/fj.00-0517fje

41. Holloszy, J., and Coyle, E. F. (1984) Adaptations of skeletal muscle to endurance exercise and their metabolic consequences. J. Cell. Physiol. 56, 831-838

42. Freake, H. C., and Oppenheimer, J. H. (1995) Thermogenesis and thyroid function. Annu. Rev. Nutr. 15, 263-291

43. Emilsson, V., O’Dowd, J., Wang, S., Liu, Y. L., Sennitt, M., Heyman, R., and Cawthorne, M. A. (2000) The effects of retinoids and rosiglitazone on body weight and uncoupling protein isoform expression in the Zucker fa/fa rat. Metabolism 49, 1610-1615
44. Samec, S., Seydoux, J., and Dulloo, A. G. (1998) Role of UCP homoloques in skeletal muscles and brown adipose tissue: mediators of thermogenesis or regulators of lipids as fuel substrate? FASEB J. 12, 715-724

45. Hamilton, J. A., and Kamp, F. (1999) How are free fatty acids transported in membranes? Is it by proteins or by free diffusion through the lipids? Diabetes 48, 2255-2269

46. Jezek, P., Orosz, D. E., Modriansky, M., and Garlid, K. D. (1994) Transport of anions and protons by the mitochondrial uncoupling protein and its regulation by nucleotides and fatty acids. A new look at old hypotheses. J. Biol. Chem. 269, 26184-26190

Received for publication June 13, 2001. Accepted for publication July 20, 2001. 